\title{
Effect of Demographic Variables on Emotional Intelligence Level in Banking Sector
}

\author{
V.Karthikeyan, Shweta Lalwani
}

\begin{abstract}
The Objective of the research was to find the differences in emotional intelligence level with regard to demographic variables pertaining to age, gender, Education level and Length of service among bank employees in India. Sample consisted of 500 respondents who are working in banks in India. Geno's Emotional Intelligence Inventory (Genos - EI) tool was used to gather data from respondents and collected data were analysed using SPSS-16. One way Anova and test were used to analyse data. Results confide that there is no significant difference in emotional intelligence levels with respect to age, gender, education level and length of service. Emotional intelligence training should be imparted on an regular basis, so that the employees working in banking sector will be able to handle the customers which in turn will benefit the organisation as well as the customer.

Key words: Age, Bank, Gender, Education, Emotional Intelligence
\end{abstract}

\section{INTRODUCTION}

Emotion is of core importance to service industry. Bank employees form and cultivate relationships within emotionally charged environments where emotion is central to the service delivery. Emotions have an impact on professional relationships, impact service delivery and affect bank employees at an intrapersonal level. In the banking sector, these actions have been consolidated through a combination of factors, including mass layoffs, automation, outsourcing, business re-engineering with the contraction of the hierarchical levels, job insecurity, the empowerment of consumers, leveraged with changes in demand patterns create added stress in the working environment. As a result, organisations invariably have to incorporate changes in business strategy, structure, process and culture to ensure continued organisational performance and to maintain competitive advantage.

Gone are those days where we talk about customer satisfaction. We have moved into an era of customer delight added to increased customer awareness and knowledge of each service.

Manuscript published on 30 September 2019

* Correspondence Author

V.Karthikeyan*, Ph.D Research Scholar, School Of Management, Sir Padampat Singhania University, Udaipur ,Rajasthan ,India

Dr.Shweta Lalwani, Assistant Professor, School Of Management, Sir Padampat Singhania University, Udaipur, Rajasthan, India

(C) The Authors. Published by Blue Eyes Intelligence Engineering and Sciences Publication (BEIESP). This is an open access article under the CC-BY-NC-ND license http://creativecommons.org/licenses/by-nc-nd/4.0/
Today, individuals are forced to work and interact on a daily basis with those from varying cultural or ethnic backgrounds, thanks to the increasing diversity in the demography of the workforce in the global economy. The professionals are demanded to communicate empathetically, competently and ethically to maintain a professional demeanor and foster a healthy work environment. In the process the professionals are fatigued and consequently deplete their emotional resources.

\section{A. Emotional Intelligence}

The concept of EI exists in different forms since from the very ancient times but gained significant consideration in the organisations after its inception by different scholars who have conducted comprehensive research on EI.

Mayer \& Salovey[1] describe emotional intelligence as, "The capability to perceive, understand, integrate emotion, facilitate thought process and to regulate emotions in order to promote personal growth.Reuven Bar-On [2] defines Emotional Intelligence as: "An array of competencies and expertise that influence an individual's ability to succeed in life and an individual's general psychological well -being". In his words "emotional intelligence comprises of abilities, competencies and skills related to understanding oneself and others, relating to peers and family members, and adapting changing environmental situations and demands". Goleman [3] defined emotional intelligence as: "The ability to be aware of and handle one's emotions in different or varying situations. It is the quality or trait in a person to monitor and regulate one's own and other's feelings and use them to guide thought and action. Emotional intelligence is increasingly important in developing people and organization, because the emotional quotient principles provide a new way to assess and understand individual behaviours, attitudes, management styles, interpersonal skills, and potential. The outlook of EI is no longer fixate upon whether emotions play a role in the work environment, but is about trying to determine the impact of using and managing emotions in the workplace and the differences between employees in dealing with emotion and the impact this may have on other variables within the work environment.

\section{B. Emotional Intelligence and its Components}

Palmer [4] developed Genos Emotional intelligence model. According to this model EI is the skill with which you identify, reveal, manage your own and other's emotions. It is a set of skill that helps us identify and respond to emotions within ourselves and others.

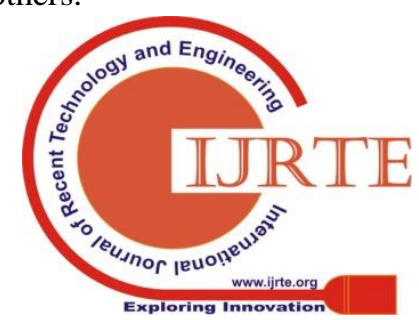


It is as important as our IQ in helping success in workplace and in our day to day life. Genos EI model consists of seven factors given in the following Figure-1.

\begin{tabular}{|c|c|c|}
\hline $\begin{array}{c}\text { Sl.N } \\
\text { o }\end{array}$ & Factor Name & Description \\
\hline 1 & $\begin{array}{l}\text { Emotional Self- } \\
\text { Awareness (ESA) }\end{array}$ & $\begin{array}{l}\text { The skill of observing and } \\
\text { comprehending your own } \\
\text { emotions }\end{array}$ \\
\hline 2 & $\begin{array}{l}\text { Emotional } \\
\text { Expression (EE) }\end{array}$ & $\begin{array}{l}\text { The skill of efficaciously } \\
\text { asserting your own } \\
\text { emotions }\end{array}$ \\
\hline 3 & $\begin{array}{l}\text { Emotional } \\
\text { Awareness of } \\
\text { others (EAO) }\end{array}$ & $\begin{array}{l}\text { The skill of observing and } \\
\text { comprehending others } \\
\text { emotions }\end{array}$ \\
\hline 4 & $\begin{array}{l}\text { Emotional } \\
\text { reasoning (ER) }\end{array}$ & $\begin{array}{l}\text { The skill of using } \\
\text { emotional information in } \\
\text { decision making }\end{array}$ \\
\hline 5 & $\begin{array}{l}\text { Emotional Self- } \\
\text { Management } \\
(\mathrm{ESM})\end{array}$ & $\begin{array}{l}\text { The skill of handling your } \\
\text { own emotions }\end{array}$ \\
\hline 6 & $\begin{array}{l}\text { Emotional } \\
\text { Management of } \\
\text { others (EMO) }\end{array}$ & $\begin{array}{l}\text { The skill of positively } \\
\text { persuading the emotions of } \\
\text { others }\end{array}$ \\
\hline 7 & $\begin{array}{l}\text { Emotional self- } \\
\text { control (ESC) }\end{array}$ & $\begin{array}{l}\text { The skill of effectively } \\
\text { controlling your own } \\
\text { strong emotions }\end{array}$ \\
\hline
\end{tabular}

Figure: 1 The Genos Model of Emotional Intelligence

Source: Palmer.B.R et.al.,"Assesing Emotional Intelligence” Page 108, [5]

\section{OBJECTIVE OF THE STUDY}

* To evaluate the effect of demographic variables on the Emotional intelligence level among bank employees

\section{HYPOTHESIS OF THE STUDY}

* $\mathrm{H}_{0}$ : There is no significant relationship between demographic variables (Gender, educational qualification, age and length of service) and EI dimensions

* $\mathrm{H}_{1}$ : There is significant relationship between demographic variables (Gender, educational qualification, age and length of service) and EI dimensions

\section{IV.LITERATURE REVIEW}

Salovey [6] on his research on American and Australian college students showed that students with high EI level, presented fewer physical symptoms, less social anxieties and depression. They have self-esteem and interpersonal satisfaction and use active coping strategies to deal their psychological problems. Jordan.P.J [7] evaluated the perception and management of EI in the workplace. Handling the proposition that intuitive commitment towards workmates is a necessary component of social interaction, they argued that the showing of positive emotions is associated with a high likelihood of success at work. Watkin
[8] in his research using Goleman's emotional intelligence framework concluded that superior leaders who exhibit higher levels of emotional intelligence lead more effectively than those with lower levels of emotional intelligence. Abraham [9] hypothesized that EI would have a positive impact on the organizational effects of work-group cohesion, agreement between self- and supervisor appraisals of performance, employee performance, organizational commitment, and organizational citizenship. Abraham concluded that the participants who recorded higher levels of EI turn to show higher levels of job performance.

Sadam Hussain Rahim [10] in his research on Emotional intelligence and organisational performance among bank employees in Pakistan found that female employees are more emotionally intelligent than their male counterpart. The study also revealed that with the increase in the level of education the emotional intelligent level also increases. Khokar and Kush [11] attempted to evaluate the performance of executives working in public and private sector on different levels of EI. Findings suggested that executives who have exhibited higher EI demonstrated better quality of work performance as related to their counterpart. Tehseen Azhar [12] conducted a research to find out the outcome of emotional intelligence on employee's job satisfaction of a private bank in Karachi on 386 employees. Results revealed that emotional intelligence acts as a stimulant on every facet in job satisfaction in a positive manner. The research also revealed that emotional intelligence also contributes and boost the efficiency and effectiveness in their respective fields. Nagar, Minakshi [13] in his research on role of demographic factors in Emotional intelligence among bank managers in India concluded that no relationship between demographic factors such as gender, educational qualifications and marital status. Sample size was 261 which involved managers working in both public and private sector banks in various parts of Rajasthan.

Mishra P.S \& Mohapatra A.D [14] explored relationship between emotional intelligence and work performance among corporate executives. Result revealed that increased emotional intelligence score were correlated with increased performance among executives working in different sectors. Work experience was found to correlate positively with EI score. Experienced executives recorded high score on EI scale as against less experienced executives. Tajeddini et.al.[15] examined the EI level among Indian and Foreign students with regard to demographic variables. Results indicated that there exists no difference between Indian and foreign students in Emotional Intelligence with regard to demographic elements related to Gender, educational qualification, Marital status, birth order, level of sociability, religion and socio economic status.

Papathanasiou, Spyros and Siati,Maria [16] on their approach to Emotional Intelligence and job satisfaction among Greek bank employees revealed that gender, age, marital status and job position affects the levels of emotional intelligence of employees in banking sector. 
It also concluded that emotional intelligence exercises an influence on the everyday life of workers and inflects the level of professional satisfaction.

\section{RESEARCH METHODOLOGY}

\section{A. Procedure and Methods}

The study was intended to explore the extent to which demographic characteristics ie gender, educational qualification, age and, length of service are related to emotional intelligence of bank employees. The current research was conducted in banks in India, particularly in South India. The mode of data collection is through structured questionnaire where the first section was related to demographic data of the respondents like age, Gender, Marital Status, Education and length of service. Second section consists of measuring Emotional Intelligence of the respondent.

\section{B. Sampling Technique}

Non probability convenience sampling is adopted in this research. Population of the study includes 500 staff members, being 267 from public sector and 233 from private sector

\section{Questionnaire}

EI was appraised by a scale developed by Dr.Palmer namely Genos Emotional Intelligence Inventory Concise (Self Assessment) version. The perceptions of the respondents were then analysed using statistical techniques like ANOVA, Correlation, one sample t-test and Multiple Regression. SPSS 16 version was used to analyse data.

\section{DATA ANALYSIS AND INTERPRETATION}

\section{A. Analysis of EI Dimensions With Respect To Gender}

To examine if there exists any difference between Gender and Emotional intelligence dimensions, Independent Sample $\mathrm{t}$ test was employed.

Table : 1 - Group Statistics of EI variable on Gender

\begin{tabular}{|c|c|c|c|c|c|}
\hline EI Dimension & Gender & $\mathbf{N}$ & Mean & Std. Deviation & $\begin{array}{l}\text { Std. Error } \\
\text { Mean }\end{array}$ \\
\hline \multirow[t]{2}{*}{ Emotional Self Awareness(ESA) } & Female & 324 & 9.99 & 1.651 & .092 \\
\hline & Male & 176 & 9.85 & 1.808 & .136 \\
\hline \multirow[t]{2}{*}{ Emotional Expression(EE) } & Female & 324 & 15.44 & 2.378 & .132 \\
\hline & Male & 176 & 15.52 & 2.347 & .177 \\
\hline \multirow[t]{2}{*}{ Emotional Awareness of Others (EAO) } & Female & 324 & 12.51 & 2.193 & .122 \\
\hline & Male & 176 & 12.77 & 1.813 & .137 \\
\hline \multirow[t]{2}{*}{ Emotional Reasoning(ER) } & Female & 324 & 15.00 & 4.083 & .227 \\
\hline & Male & 176 & 14.90 & 4.204 & .317 \\
\hline \multirow[t]{2}{*}{ Emotional Self Management(ESM) } & Female & 324 & 13.65 & 2.238 & .124 \\
\hline & Male & 176 & 13.66 & 2.025 & .153 \\
\hline \multirow[t]{2}{*}{ Emotional Management of Others (EMO) } & Female & 324 & 12.21 & 2.671 & .148 \\
\hline & Male & 176 & 12.46 & 2.307 & .174 \\
\hline \multirow[t]{2}{*}{ Emotional Self- Control (ESC) } & Female & 324 & 12.86 & 2.003 & .111 \\
\hline & Male & 176 & 12.85 & 2.020 & .152 \\
\hline \multirow[t]{2}{*}{ Emotional Intelligence (EI) } & Female & 324 & 91.66 & 6.792 & .377 \\
\hline & Male & 176 & 92.02 & 6.744 & .508 \\
\hline
\end{tabular}

It is evident from table 2, that there is no significant difference in the mean scores of female and male respondents on the EI dimensions of ESA, EE, EAO, ER, ESM, EMO and ESC. The overall EI mean score for female and male are 91.66 and 92.02 . 
Effect of Demographic Variables on Emotional Intelligence Level in Banking Sector

Table: 2 - Independent sample t-test for Gender comparison among EI variables

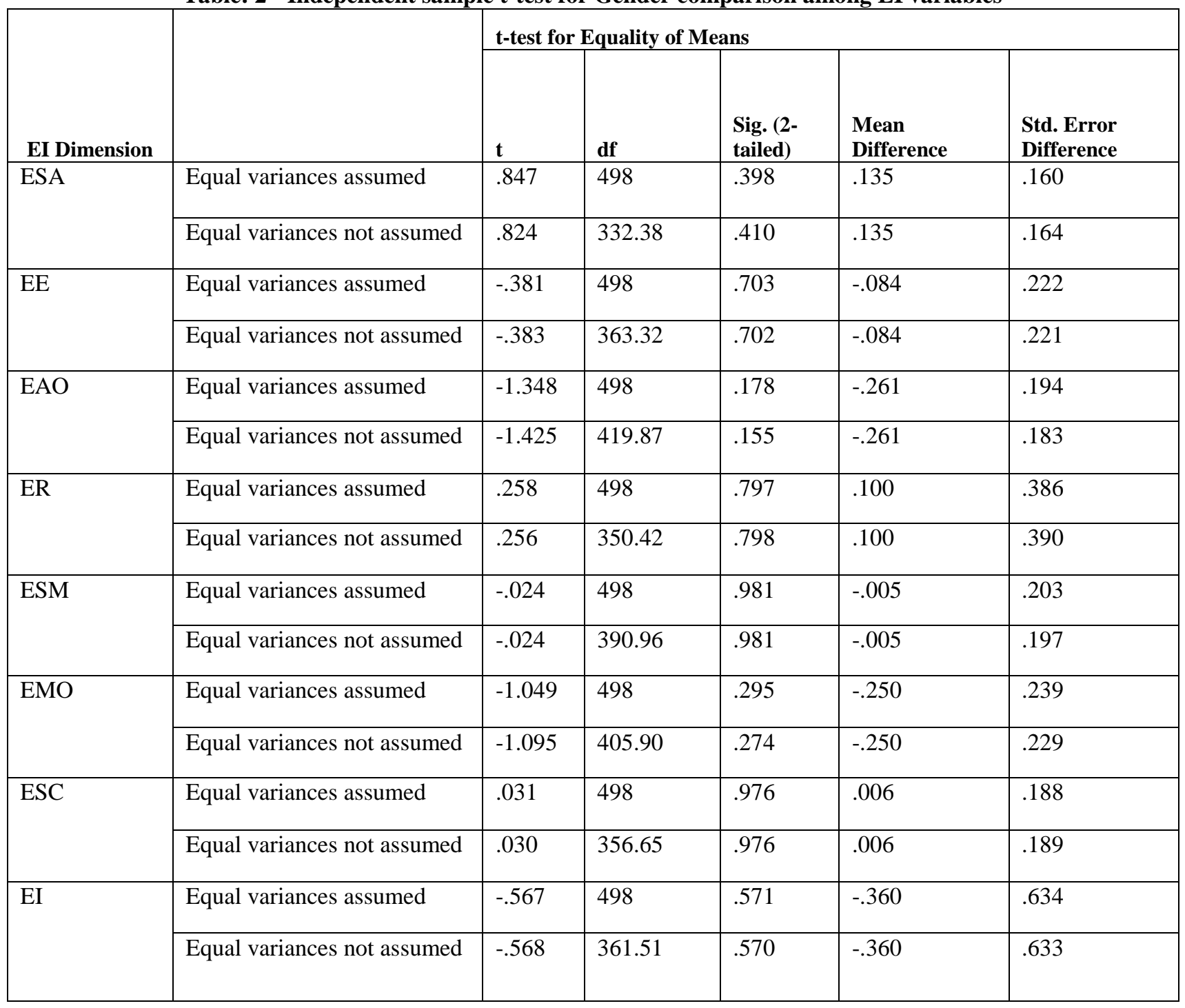

Table: 2 depict the independent t test for EI variables. Their statistical interpretation are given below

\begin{tabular}{|l|c|c|c|}
\hline \multicolumn{1}{|c|}{ EI Dimension } & p value & Significance Level & Inference \\
\hline ESA & 0.398 & $\mathrm{p}=0.398>0.005$ & \multirow{2}{*}{ Not Statistically different } \\
\hline EE & 0.703 & $\mathrm{p}=0.703>0.005$ \\
\hline EAO & 0.178 & $\mathrm{p}=0.178>0.005$ & \multirow{2}{*}{$\mathrm{p}=0.797>0.005$} \\
\hline ER & 0.797 & $\mathrm{p}=0.981>0.005$ \\
\hline ESM & 0.981 & $\mathrm{p}=0.295>0.005$ \\
\hline EMO & 0.295 & $\mathrm{p}=0.976>0.005$ \\
\hline ESC & 0.976 & $\mathrm{p}=0.571>0.005$ & \\
\hline EI & 0.571 & & \\
\hline
\end{tabular}

\section{Conclusion:}

It is observed that the male and female respondents are statistically not different in terms of EI variables

\section{B. Analysis Of EI Dimensions With Respect To Education}

To examine if there exists any difference between Educational level and Emotional intelligence dimensions, Independent Sample t test was employed 
Table : 3 - Group Statistics of EI variables on Education

\begin{tabular}{|c|c|c|c|c|c|}
\hline EI Dimension & Education & $\mathbf{N}$ & Mean & $\begin{array}{l}\text { Std. } \\
\text { Deviation }\end{array}$ & $\begin{array}{l}\text { Std. Error } \\
\text { Mean }\end{array}$ \\
\hline \multirow[t]{2}{*}{ ESA } & Graduate & 369 & 9.96 & 1.668 & .087 \\
\hline & Post Graduate & 131 & 9.89 & 1.817 & .159 \\
\hline \multirow[t]{2}{*}{$\mathrm{EE}$} & Graduate & 369 & 15.50 & 2.380 & .124 \\
\hline & Post Graduate & 131 & 15.39 & 2.329 & .203 \\
\hline \multirow[t]{2}{*}{ EAO } & Graduate & 369 & 12.60 & 2.041 & .106 \\
\hline & Post Graduate & 131 & 12.58 & 2.155 & .188 \\
\hline \multirow[t]{2}{*}{ ER } & Graduate & 369 & 15.05 & 4.124 & .215 \\
\hline & Post Graduate & 131 & 14.75 & 4.126 & .360 \\
\hline \multirow[t]{2}{*}{ ESM } & Graduate & 369 & 13.67 & 2.107 & .110 \\
\hline & Post Graduate & 131 & 13.61 & 2.322 & .203 \\
\hline \multirow[t]{2}{*}{ EMO } & Graduate & 369 & 12.42 & 2.615 & .136 \\
\hline & Post Graduate & 131 & 11.96 & 2.332 & .204 \\
\hline \multirow[t]{2}{*}{ ESC } & Graduate & 369 & 12.84 & 1.984 & .103 \\
\hline & Post Graduate & 131 & 12.89 & 2.076 & .181 \\
\hline \multirow{2}{*}{$\begin{array}{l}\text { Emotional } \\
\text { Intelligence }\end{array}$} & Graduate & 369 & 92.04 & 6.815 & .355 \\
\hline & Post Graduate & 131 & 91.07 & 6.616 & .578 \\
\hline
\end{tabular}

It is evident from table 4, that there moderate difference was observed in the mean scores of female and male respondents on the EI dimensions of ESA, EE, EAO, ER, ESM, EMO and ESC. The overall EI mean score for graduate and Post graduate are 92.04 and 91.07

Table: 4 - Independent sample t-test for Educational level among EI variables

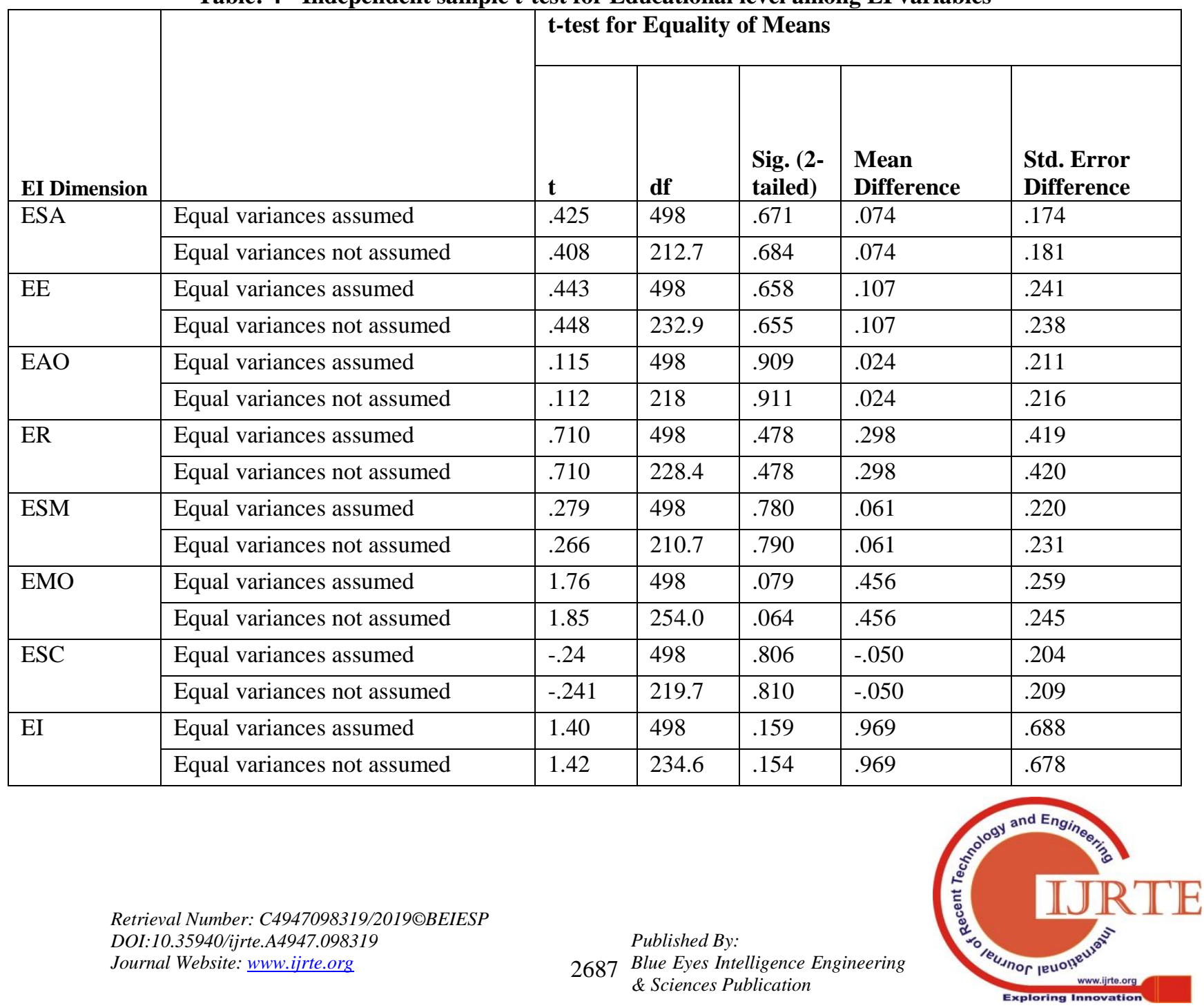


Effect of Demographic Variables on Emotional Intelligence Level in Banking Sector

Table: 4 depict the independent $t$ test for EI variables. Their statistical interpretation are given below

\begin{tabular}{|l|c|c|c|}
\hline \multicolumn{1}{|c|}{ EI Dimension } & p value & Significance Level & Inference \\
\hline ESA & 0.671 & $\mathrm{p}=0.671>0.005$ & \\
\hline EE & 0.678 & $\mathrm{p}=0.678>0.005$ \\
\hline EAO & 0.909 & $\mathrm{p}=0.909>0.005$ & \multirow{3}{*}{ Not Statistically different } \\
\hline ER & 0.478 & $\mathrm{p}=0.478>0.005$ & \\
\hline ESM & 0.780 & $\mathrm{p}=0.780>0.005$ & \\
\hline EMO & 0.079 & $\mathrm{p}=0.079>0.005$ \\
\hline ESC & 0.806 & $\mathrm{p}=0.8060 .005$ \\
\hline EI & 0.159 & $\mathrm{p}=0.159>0.005$ & \\
\hline
\end{tabular}

\section{Conclusion:}

It is observed that the graduate and post graduate respondents are statistically not different in terms of EI variables.

\section{Analysis of EI Dimensions With Respect To Age Group}

To examine if there exists any difference in age group of the respondents and Emotional intelligence dimensions, one way ANOVA was conducted

Table: 5: ANOVA test for age groups with respect to the dimensions of emotional intelligence

\begin{tabular}{|c|c|c|c|c|c|c|c|}
\hline \multirow[b]{2}{*}{$\begin{array}{c}\text { EI } \\
\text { Dimension }\end{array}$} & \multicolumn{4}{|c|}{ Age group in years } & \multirow[b]{2}{*}{ Total } & \multirow[b]{2}{*}{ F value } & \multirow[b]{2}{*}{ Sig. } \\
\hline & $\begin{array}{l}\text { Below } 30 \\
\text { years }\end{array}$ & $\begin{array}{l}31-40 \\
\text { years }\end{array}$ & $\begin{array}{l}41-50 \\
\text { Years }\end{array}$ & $\begin{array}{l}\text { Above } 50 \\
\text { years }\end{array}$ & & & \\
\hline ESA & $\begin{array}{c}9.87 \\
(1.62)\end{array}$ & $\begin{array}{l}10.02 \\
(1.64)\end{array}$ & $\begin{array}{l}10.09 \\
(1.80)\end{array}$ & $\begin{array}{c}9.85 \\
(1.78)\end{array}$ & $\begin{array}{c}9.94 \\
(1.70)\end{array}$ & 0.533 & 0.660 \\
\hline $\mathrm{EE}$ & $\begin{array}{l}15.29 \\
(2.40)\end{array}$ & $\begin{array}{l}15.34 \\
(2.39)\end{array}$ & $\begin{array}{l}15.46 \\
(2.30)\end{array}$ & $\begin{array}{l}15.76 \\
(2.34)\end{array}$ & $\begin{array}{l}15.47 \\
(2.3)\end{array}$ & 1.10 & 0.346 \\
\hline EAO & $\begin{array}{l}12.55 \\
(1.95)\end{array}$ & $\begin{array}{l}12.59 \\
(2.00)\end{array}$ & $\begin{array}{l}12.65 \\
(2.34)\end{array}$ & $\begin{array}{l}12.62 \\
(2.07)\end{array}$ & $\begin{array}{l}12.60 \\
(2.06)\end{array}$ & .049 & 0.986 \\
\hline ER & $\begin{array}{l}14.73 \\
(4.15)\end{array}$ & $\begin{array}{l}14.60 \\
(4.15)\end{array}$ & $\begin{array}{l}15.31 \\
(4.41)\end{array}$ & $\begin{array}{l}15.30 \\
(3.86)\end{array}$ & $\begin{array}{l}14.97 \\
(4.12)\end{array}$ & .993 & 0.396 \\
\hline ESM & $\begin{array}{l}13.58 \\
(1.95)\end{array}$ & $\begin{array}{l}13.83 \\
(2.19)\end{array}$ & $\begin{array}{l}13.60 \\
(2.24)\end{array}$ & $\begin{array}{l}13.61 \\
(2.28)\end{array}$ & $\begin{array}{l}13.66 \\
(2.16)\end{array}$ & .381 & 0.766 \\
\hline EMO & $\begin{array}{l}12.39 \\
(2.2)\end{array}$ & $\begin{array}{l}12.43 \\
(2.81)\end{array}$ & $\begin{array}{l}12.18 \\
(2.59)\end{array}$ & $\begin{array}{l}12.17 \\
(2.58)\end{array}$ & $\begin{array}{l}12.30 \\
(2.54)\end{array}$ & .358 & 0.784 \\
\hline ESC & $\begin{array}{l}12.82 \\
(1.98)\end{array}$ & $\begin{array}{l}12.79 \\
(1.99)\end{array}$ & $\begin{array}{l}12.85 \\
(2.00)\end{array}$ & $\begin{array}{l}12.95 \\
(2.06)\end{array}$ & $\begin{array}{l}12.86 \\
(2.07)\end{array}$ & .161 & 0.922 \\
\hline Total EI & $\begin{array}{l}91.23 \\
(6.87)\end{array}$ & $\begin{array}{l}91.60 \\
(6.53)\end{array}$ & $\begin{array}{l}92.13 \\
(7.09)\end{array}$ & $\begin{array}{l}92.25 \\
(6.68)\end{array}$ & $\begin{array}{l}91.78 \\
(6.77)\end{array}$ & .643 & 0.588 \\
\hline
\end{tabular}

Note: The value within bracket refers to SD

Degrees of Freedom (df): Between Groups: 3 Within Groups : 496

In the above table 5,the dimensions of Emotional Intelligence are compared with different age groups .The significance value for ESA, EE, EAO, ER.ESM,EMO and ESC are $0.660,0.346,0.986,0.396,0.766,0.784,0.922$ respectively which is greater than the significance limit $(\mathrm{P}>0.05)$. It exhibits that there is no significant relationship between EI dimensions and Age group.

The overall value of $\mathrm{F}=.64$, and significance value $p=.58$, which is greater than the significance limit $(\mathrm{P}>0.05)$. The fact that the $p$ value is greater than .05 , we conclude that there exists no significant differences in emotional Intelligence among different age groups. The mean Emotional Intelligence is 92.25 and SD is 6.67. There were slight differences in the mean emotional intelligence for different age groups with those older age group generally having a higher mean compared to those younger.

\section{Analysis of EI Dimensions With Respect To Length Of Service}

To examine if there exists any difference in length of service of the respondents and Emotional intelligence dimensions, one way ANOVA was conducted. 
Table 6: ANOVA test for Length of service in years with respect to the dimensions of emotional intelligence

\begin{tabular}{|c|c|c|c|c|c|c|c|c|c|}
\hline \multirow{2}{*}{$\begin{array}{c}\text { EI } \\
\text { Dimension }\end{array}$} & \multicolumn{6}{|c|}{ Length of Service } & \multirow[b]{2}{*}{ Total } & \multirow[b]{2}{*}{ F value } & \multirow[b]{2}{*}{ Sig. } \\
\hline & 0-5 yrs & $6-10$ yrs & $\begin{array}{c}\text { 11-15 } \\
\text { yrs }\end{array}$ & $\begin{array}{c}16-20 \\
\text { yrs }\end{array}$ & $\begin{array}{c}21-25 \\
\text { yrs }\end{array}$ & $\begin{array}{c}26 \text { yrs \& } \\
\text { Above }\end{array}$ & & & \\
\hline ESA & $\begin{array}{l}9.85 \\
(1.67) \\
\end{array}$ & $\begin{array}{l}9.89 \\
(1.53) \\
\end{array}$ & $\begin{array}{l}10.41 \\
(1.80) \\
\end{array}$ & $\begin{array}{l}9.86 \\
(1.66) \\
\end{array}$ & $\begin{array}{l}10.02 \\
(1.74)\end{array}$ & $\begin{array}{l}9.67 \\
(1.96)\end{array}$ & $\begin{array}{l}9.94 \\
(1.70)\end{array}$ & 1.13 & 0.34 \\
\hline $\mathrm{EE}$ & $\begin{array}{l}15.2 \\
(2.37)\end{array}$ & $\begin{array}{l}15.70 \\
(2.40)\end{array}$ & $\begin{array}{l}15.24 \\
(2.17)\end{array}$ & $\begin{array}{l}15.39 \\
(2.43)\end{array}$ & $\begin{array}{l}15.96 \\
(2.41)\end{array}$ & $\begin{array}{l}15.21 \\
(2.04)\end{array}$ & $\begin{array}{l}15.47 \\
(2.37)\end{array}$ & 1.74 & 0.12 \\
\hline EAO & $\begin{array}{l}12.48 \\
(2.08)\end{array}$ & $\begin{array}{l}12.60 \\
(1.71)\end{array}$ & $\begin{array}{l}12.35 \\
(2.01)\end{array}$ & $\begin{array}{l}13.08 \\
(2.01)\end{array}$ & $\begin{array}{l}12.63 \\
(2.28)\end{array}$ & $\begin{array}{l}12.42 \\
(2.01)\end{array}$ & $\begin{array}{l}12.60 \\
(2.07)\end{array}$ & 1.1 & 0.35 \\
\hline ER & $\begin{array}{l}14.6 \\
(4.05)\end{array}$ & $\begin{array}{l}14.49 \\
(4.12)\end{array}$ & $\begin{array}{l}14.96 \\
(4.26)\end{array}$ & $\begin{array}{l}15.04 \\
(4.33)\end{array}$ & $\begin{array}{l}15.56 \\
(4.08)\end{array}$ & $\begin{array}{l}15.52 \\
(3.89)\end{array}$ & $\begin{array}{l}14.97 \\
(4.12)\end{array}$ & 1.01 & 0.4 \\
\hline ESM & $\begin{array}{l}13.52 \\
(2.12)\end{array}$ & $\begin{array}{l}13.81 \\
(1.96)\end{array}$ & $\begin{array}{l}14.61 \\
(1.94)\end{array}$ & $\begin{array}{l}13.46 \\
(2.05)\end{array}$ & $\begin{array}{l}13.39 \\
(2.42)\end{array}$ & $\begin{array}{l}13.94 \\
(1.98)\end{array}$ & $\begin{array}{l}13.66 \\
(2.16)\end{array}$ & 2.8 & 0.01 \\
\hline EMO & $\begin{array}{l}12.45 \\
(2.24)\end{array}$ & $\begin{array}{l}12.0 \\
(2.68)\end{array}$ & $\begin{array}{l}12.35 \\
(3.46)\end{array}$ & $\begin{array}{l}12.15 \\
(2.23)\end{array}$ & $\begin{array}{l}12.23 \\
(2.64)\end{array}$ & $\begin{array}{l}12.58 \\
(2.53)\end{array}$ & $\begin{array}{l}12.30 \\
(2.55)\end{array}$ & 0.425 & 0.83 \\
\hline ESC & $\begin{array}{l}12.72 \\
(2.02)\end{array}$ & $\begin{array}{l}13.05 \\
(1.93)\end{array}$ & $\begin{array}{l}12.45 \\
(2.02)\end{array}$ & $\begin{array}{l}13.24 \\
(2.01)\end{array}$ & $\begin{array}{l}12.98 \\
(1.87)\end{array}$ & $\begin{array}{l}12.55 \\
(2.53)\end{array}$ & $\begin{array}{l}12.86 \\
(2.00)\end{array}$ & 1.46 & 0.2 \\
\hline Total EI & $\begin{array}{l}90.81 \\
(6.59)\end{array}$ & $\begin{array}{l}91.54 \\
(6.48)\end{array}$ & $\begin{array}{l}92.37 \\
(7.44)\end{array}$ & $\begin{array}{l}92.22 \\
(6.40)\end{array}$ & $\begin{array}{l}92.77 \\
(7.11)\end{array}$ & $\begin{array}{l}91.88 \\
(6.57)\end{array}$ & $\begin{array}{l}91.78 \\
(6.77)\end{array}$ & 1.33 & 0.24 \\
\hline
\end{tabular}

Note: The value within bracket refers to SD

Degrees of Freedom (df): Between Groups: 5 Within Groups : 494

In the above ANOVA Table 7,the dimensions of Emotional Intelligence are compared with length of service. The significance value for ESA, EE, EAO, ER.ESM,EMO and ESC are0.34,0.12,0.35,0.4,0.01,0.83,0.2 respectively which is greater than the significance limit $(\mathrm{P}>0.05)$ except for ESM which is0.01. It implies that there is no significant relationship between EI dimensions and length of service The overall value of $\mathrm{F} 1.33$, and significance value $p=.24$, which is greater than the significance limit $(\mathrm{P}>0.05)$.The fact that the $p$ value is greater than .05 , we conclude that that there are no significant differences in emotional Intelligence between the length of service. The mean Emotional Intelligence is 91.78 and SD is 6.77 .

\section{CONCLUSION:}

Employee is the key asset for any organization. No organization can succeed without employee's contribution. In recent times, great emphasis has been laid by organizations to explore conditions that promote greater employee working environment. The fact to be relied upon is that the performance of satisfied employees will make positive contributions which in turn will increase organizational effectiveness and performance. Gone are those days where we talk about customer satisfaction. The present competitive business expects customer delight. The present research helped in understanding effect of demographic elements on the emotional intelligence level. Results of the study have conclusively proved that there is no difference in emotional intelligence level with respect to the demographic factors such as age, gender, length of service and educational level among bank employees thereby accepting our alternate hypothesis. Employees need to gear up and update themselves in enhancing their customer interaction, for which they should be emotionally capable to handle customers in highly stressful conditions.

\section{REFERENCES}

1. Salovey,P \& Mayer,J.D.(1997).What is emotional intelligence ? Emotional Development andEmotional Intelligence: Educational Implications: Pp 3-31,Newyork: Basic Books

2. Bar-On, R. (1997). The Emotional Quotient Inventory (EQ-i): A test of emotional intelligence. Toronto,canada: Multi-Health Systems, Inc

3. Goleman, D. (1998). What makes a leader? Harvard Business Review 93-102,Product Number:3790.

4. Palmer.B. (2001). Emotional Intelligence and effective leadership Leadership and Organisation development journal , 5-10.

5. Palmer R.Benjamin, Stough Con, Harner Richard and Gignac Gilles (2003), The genos Emotional Intelligence Inventory:A measure designed specifically for workplace applications, Page 108.

6. Salovey.P,Stroud.L.R,Woolery.A and Epel.E.S.,(2002) "Perceived emotional intelligence, stress reactivity, and symptom reports: further explorations using the trait meta-mood scale", Psychol.Health 17, 611627 (2002)

7. Jordan.P.J, A. H. (2002). Workgroup emotional intelligence: Scale development and relationship to team process effectiveness and goal focus. HumanResource Management Review , pp. 195-214.

8. Watkin.,'Developing Emotional Intelligence", International Journal of selection and assessment, 8(2)89-92 (2000)

9. Abraham.R. (1999). In Emotional Intelligence in organisatons: A conceptualisation. Genetic, social and general Monographs,125(2) (pp. 209-224)

10. Saddam Hussain Rahim., M. I. (2010). Emotional Intelligence and Organisational Performance: A case study of Banking Sector in Pakistan. International Journal of Business and Management, 191-197

11. Khokhar,C.P., \& Kush, T. (2009). Emotional intelligence and work performance among executives,Europe's Journal of Psychology, 5(1) $1-11$.

12. Tehseen Azhar.T. H.,"Effect of Emotional Intelligence on Employee's Job Satisfaction : A Case of Private Bank in Karachi ". European Journal of Business and Management , 6(14),184-193 (2014)

13. Nagar,Minakshi (2017) Role of Demographic factors in Emotional Intelligence : An empirical study of Bank Managers, Indian Journal of Commerce andManagement studies, Volume 8 . Issue -3 , Pp26-32

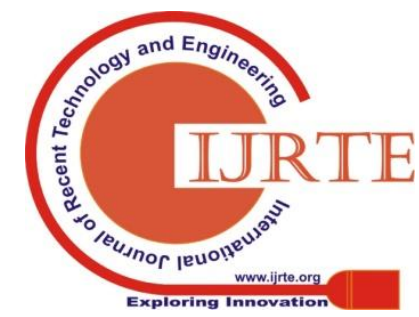


14. Mishra, P. S., \& Mohapatra, A. D. (2010). Relevance of emotional intelligence for effective job performance: An empirical study. Vikalpa, 35(1), 53-61.

15. Tajeddini, R., Rangan, U., Malekzadeh, M., \& Lallianzuali, C. (2014) Global Emotional Intelligence and Six Dimensions of Emotional Intelligence in Indian and Foreign Students with respect to Demographic Variables-(A Comparative Study), IOSR Journal of Humanities and Social Science IOSR JHSS), 19(5), 94-104

16. Spyros Papathanasiou, Maria Siati (2014). Emotional Intelligence and Job Sartisfaction among Greek bank Employees, Research In Applied Economics,Vol.6, No1 (2014), pp 225-239

\section{AUTHORS PROFILE:}

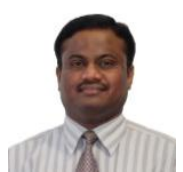

V.Karthikeyan is currently pursuing Ph.D in Management from Sir Padampat Singhania University,Udaipur.He has done MBA with specialisation in Hospital and Health Systems Management from Sri Ramachandra Institute of Higher Education and Research, Chennai.

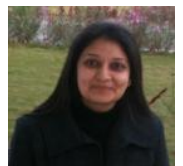

Dr.Shweta Lalwani is Assistant Professor, School of Management, Sir Padampat Singhania University, Udaipur. An MBA(Hons.)\& Ph.D. in Management from Jai Narain Vyas University, Jodhpur. She has been in academics for more than a decade. She has to her credit a Research Project funded by ICSSR in the area of OB. She is the Project coordinator for the University International Project funded by European Union. She has published articles in reputed management journals and has presented a number of papers in National and International conferences in HRM, OB and General Management areas. Her research interests are Recruitment and Selection procedures, Selection tests, Succession Planning, Methods of Training and Development, Compensation management, Career Planning, Green HRM, e-HR activities, Cross-cultural issues, International HRM, Leadership, Job Satisfaction, Motivation Theories \&Techniques. 